\title{
Bischofia and Hymenocardia (Phyllanthaceae) in Malesia
}

\author{
P.C. van Welzen ${ }^{1,2}$
}

Key words

Bischofia

Euphorbiaceae

Hymenocardia

Malesia

Phyllanthaceae
Abstract The genera Bischofia and Hymenocardia both have a single species in Malesia. The two genera were always difficult to classify, both once formed their own family, but are now firmly embedded in the Phyllanthaceae. Of both genera a more complete nomenclature and biogeography is presented.

Published on 9 December 2016

\section{INTRODUCTION}

Bischofia Blume and Hymenocardia Wall. ex Lindl. have an interesting taxonomic past. Recent phylogenetic analyses based on five genes (atpB, matK, ndhF, PHYC, rbcL; Hoffmann et al. 2006, modified from Kathriarachchi et al. 2005) show that Bischofia and Hymenocardia are part of the Phyllanthaceae subfamily Antidesmatoideae Hurus. Bischofia occupies a basal position in the phylogeny (Hoffmann et al. 2006: f. 1) and forms the monotypic tribe Bischofieae Hurus. (Hoffmann et al. 2006). Hymenocardia is part of tribe Antidesmateae Benth. and within this tribe it is classified in subtribe Hymenocardiinae Petra Hoffm. together with Didymocistus Kuhlm. Levin (1986) already showed in a cladistic analysis based on leaf morphology and leaf anatomical characters that both genera are Phyllanthoid. In former times both genera have wandered around in the classification of the Malphigiales. Bischofia was regarded as a tribe of the Euphorbiaceae by Hurusawa (1954, as 'Bischoffieae'), but in the same family the genus has also been classified as subtribe Bischofiinae (Müller 1865, as 'Bischoffieae') or it was recognized as the separate family Bischofiaceae (Airy Shaw 1964) close to the Euphorbiaceae (Radcliffe-Smith 1987).

Hymenocardia has a comparable history, Hutchinson (1969) regarded it as tribe Hymenocardieae within the Euphorbiaceae and Airy Shaw (1964) gave it family status (Hymenocardiaceae), also close to the Euphorbiaceae (Radcliffe-Smith 1987). The status of tribe Hymenocardieae and the number of genera included were variable, the circumscription of Hutchinson was much wider (e.g., including Aporosa Blume, Aporosella Chodat (synonym of Phyllanthus L.), Baccaurea Lour., Didymocistus and Martretia Beille) than that of Webster $(1994,2014)$ and Radcliffe-Smith (2001), where only Didymocistus is still included in the tribe.

If the Phyllanthaceae are still regarded as part of the Euphorbiaceae, then both genera are classified in subfamily Phyllanthoideae Asch., Bischofia in tribe Bischofieae (Müll.Arg.) Hurus. and Hymenocardia in tribe Hymenocardieae Hutch. (Webster 1994, 2014, Radcliffe-Smith 2001).

\footnotetext{
1 Naturalis Biodiversity Center, research group Biodiversity Discovery, P.O. Box 9517, 2300 RA Leiden, The Netherlands;

e-mail: peter.vanwelzen@naturalis.nl.

2 Institute of Biology Leiden, Leiden University, P.O. Box 9505, 2300 RA Leiden, The Netherlands.
}

The two genera have several characters that are aberrant within the Euphorbiaceae s.I., which has caused their classification problems. Bischofia is exceptional because of its 3-foliolate leaves (in Malesia also found in - the introduced - Hevea Aubl. and Annesijoa Pax \& K.Hoffm., with digitate leaves) and lack of a disc (also lacking in Hymenocardia). Hymenocardia has samara-like fruits (which are true regmas) and disc-like glandular hairs (resembling those of Homonoia Lour., Macaranga Thouars, Mallotus Lour., and Pantadenia Gagnep.).

\section{BISCHOFIA}

Bischofia is typified by the generally 3-foliolate leaves, flowers lacking petals and a disc, and drupaceous fruits. Bischofia was named by Blume (1826-1827) after G.W.T.G. Bischoff, a botanist from Heidelberg, Germany (1797-1854). Because of the double ' $f$ ' at the end of Bischoff's name and the use of a single ' $f$ ' by Blume, confusion arose about the correct spelling. Especially the earliest publications after Blume 'corrected' the name to Bischoffia.

The genus contains two species, $B$. javensis Blume, widespread in Asia, Australia and the Pacific; and from China B. polycarpa (H.Lév.) Airy Shaw (1972b, based on Celtis polycarpa H.Lév., Ulmaceae), including the synonym B. racemosa W.C.Cheng \& C.D.Chu ex Yi F.Duan \& X.R.Wang (Duan et al. 2016). Bischofia polycarpa, not treated here, differs from $B$. javensis in having thinner, more densely veined leaflets (vs more coriaceous, less densely veined in $B$. javensis) that are generally broadly elliptic to almost suborbicular (vs elliptic to oblong in B. javensis), delicate, (unbranched) racemose pistillate inflorescences (vs more sturdy and paniculate in B. javensis), and smaller fruits (bigger in B. javensis) (Airy Shaw 1972b). Some of the characters are difficult to interpret. Both species are deciduous with the leaves appearing during flowering. These young leaves are thin in both species, thus the texture can only be measured when they are in fruit. Also the size of the fruits is difficult, because the maturity of the fruits is not easy to assess from herbarium specimens. Likewise, the branching of the inflorescence is variable in $B$. javanica, more northern specimens often also have unbranched inflorescences. Character differences mentioned in the Flora of China (Li \& Gilbert 2008) are partly also not applicable, both species are deciduous, also $B$. javanica, and the sole specimen of $B$. polycarpa in $L$ does not really have a rounded leaf blade base. It seems that $B$. polycarpa is often 2-locular 
(vs 3-locular) and the Leiden specimen has an ovate (instead of elliptic) leaflet blade and the fruits have on top a short style (absent in B. javanica) and shorter stigmas than B. javanica.

One character not mentioned for Bischofia so far, is the presence of domatia on the lower leaf surface between midrib and secondary veins and/or in axils of secondary and tertiary veins. These are holes or more or less sac-like (walled and sometimes with roof).

Bischofia javanica, a pioneer species, is invasive in the Bonin Islands (Japan) due to its rapid germination in open places (Hata et al. 2006) and adaptability to dry periods via leaf shedding (Yazaki et al. 2015).

\section{Bischofia Blume}

Bischofia Blume (1826-1827) 1168; Endl. (1840) 1149; Decne. (1842) 580 ('Bischoffia'); Hassk. (1844) 250 ('Bischoffia'); Hook. (1852) t. 844; Baill. (1858) 594; Miq. (1859) 363; (1860) 178, 444; Müll.Arg. (1866) 478 ('Bischoffia'); Bedd. (1872) pl. 259 ('Bischoffia'); Brandis (1874) 445 ('Bischoffia'); Kurz (1877) 355 ('Bischoffia'); Gamble (1881) 355 ('Bischoffia'); Benth. (1880) 281; Hook.f. (1887) 344; Pax (1890) 33; J.J.Sm. (1910) 290; Pax \& K.Hoffm. (1922) 312 ('Bischoffia'); Gagnep. (1927) 542; Pax \& K.Hoffm. (1931) 78; Hurus. (1954) 339 ('Bischoffia'); Backer \& Bakh.f. (1963) 473; Airy Shaw (1972a) 271; A.C.Sm. (1981) 494; Radcl.-Sm. (1987) 54; G.L.Webster (1994) 54; Govaerts et al. (2000) 264; Radcl.-Sm. (2001) 77; Welzen (2005) 122; P.T.Li (Li BT) \& M.G.Gilbert (2008) 217; G.L.Webster (2014) 89.- Type: Bischofia javanica Blume.

Microelus Wight \& Arn. (1833) 298. - Type: Microelus roeperianus (= Bischofia javanica Blume).

Stylodiscus Benn. (1840) 133. - Type: Andrachne trifoliata Roxb. (Stylodiscus trifoliatus (Roxb.) Benn.) (= Bischofia javanica Blume).

Tree, dioecious, deciduous (flowering when in young leaf), latex red. Indumentum simple hairs, only very locally present. Stipules falcate, early caducous. Leaves alternate, 3-foliolate (to 5-imparipinnate), usually crowded at end of branchlets, petiole long; leaflets symmetric, basally attached, margin (serrulate to) serrate with sharp teeth, without glands, sometimes seemingly entire in old leaves, surfaces smooth, (sub)glabrous, lower surface usually with (sac-like or hole) domatia in axils of midrib and secondary veins and/or in the axils of secondary and tertiary veins; venation pinnate, nerves seemingly looped and closed near margin, veins indistinctly reticulate. Inflorescences axillary to pseudoterminal racemes (B. racemosa) or panicles (B. javanica), pendulous in fruit; flowers single per bract; bracts early caducous. Flowers actinomorphic; sepals 5, free; petals and disc absent. Staminate flowers: pedicel with sub- basal abscission zone; sepals hooded around stamens when young, reflexing, valvate; receptacle torus-like, with stamens attached below pistillode; stamens 5, episepalous, filament short, anthers large, latrorse, thecae two, connective narrow; pistillode 5-lobed, infundibuliform. Pistillate flowers: pedicel with abscission zone in \pm middle; sepals imbricate, flat; staminodes absent or early caducous, small, strap-like; ovary 3(-4)-locular, globose; ovules 2 per locule; style short, stigmas long, apically entire, upper surface with stigmatic tissue. Fruits drupes, (sub)globose, smooth, mesocarp fleshy, endocarp woody. Seeds obovoid, rather crescent-moon-shaped, smooth, naked.

Distribution - Two species, one locally in China, the other from India to the Pacific.

\section{Bischofia javanica Blume - Fig. 1; Map 1}

Bischofia javanica Blume (1826-1827) 1168; Hassk. (1844) 250 ('Bischoffia'); Decne. (1844) 153; Miq. (1859) 363; Müll.Arg. (1866) 478 ('Bischoffia'); Bedd. (1872) pl. 259 ('Bischoffia'); Brandis (1874) 446 ('Bischoffia'); Kurz (1877) 355 ('Bischoffia'); Gamble (1881) 355 ('Bischoffia'); Hook.f. (1887) 345; J.J.Sm. (1910) 291; Pax \& K.Hoffm. (1922) 313, f. 26 ('Bischoffia'); Gagnep. (1927) 542, f. 66: 15-18; f. 67: 6-10; Hurus. (1954) 339 ('Bischoffia'); Backer \& Bakh.f. (1963) 474; A.C.Sm. (1981) 495; Radcl.-Sm. (1987) 54, f. 7; Welzen (2005) 124, f. 26, pl. V: 2; (2007) 610, f. 1; P.T.Li (Li BT) \& M.G.Gilbert (2008) 217. - Bischofia javanica Blume var. genuina Müll. Arg. (1866) 478 ('Bischoffia'), nom. illeg. - Lectotype (designated here): Anonymous (Blume) s.n., s.d. (L, L0448126), Java.

Andrachne trifoliata Roxb. (1832) 728. - Stylodiscus trifoliatus (Roxb.) Benn. (1840) 133, t. 29. - Bischofia trifoliata (Roxb.) Hook. (1852) t. 844. - Bischofia javanica Blume var. lanceolata Müll.Arg. (1866) 479 ('Bischoffia'). - Lectotype (designated here): Roxburgh plate 1698 (CAL), India (see note).

Microelus roeperianus Wight \& Arn. (1833) 298; Wight (1852) t. 1880. Bischofia roeperiana (Wight \& Arn.) Decne. (1844) 153; Baill. (1858) 595, pl. 26, f. 25-32 ('Bischoffia'). - Lectotype (designated here, following Hooker 1887): R. Wight 941 (E, E00179541; iso BR, E 4 sheets, G-DC, K 2 sheets), Peninsula Ind. orientalis.

Bischofia oblongifolia Decne. (1844) 152, t. 153 (in text 'tab. 154'). Bischofia javanica Blume var. oblongifolia (Decne.) Müll.Arg. (1866) 479 ('Bischoffia'). - Type: Not indicated.

Bischofia toui Decne. (1844) 153. - Bischofia javanica Blume var. toui (Decne.) Müll.Arg. (1866) 478 ('Bischoffia'). - Type: Not indicated.

[Andrachne apetala Roxb. ex Wall. (1847) 7956A, nom. inval., nom. nud.] Bischofia leptopoda Müll.Arg. (1866) 479 ('Bischoffia'). — Type: Herbarium of the U.S. Exploring Expedition under the command of Capt. Wilkes s.n.' 1865 (holo G-DC), Tonga.

Phyllanthus ? gymnanthus Baill. (1862) 240 - Type: Vieillard 1162 (P), New Caledonia, Kanala.

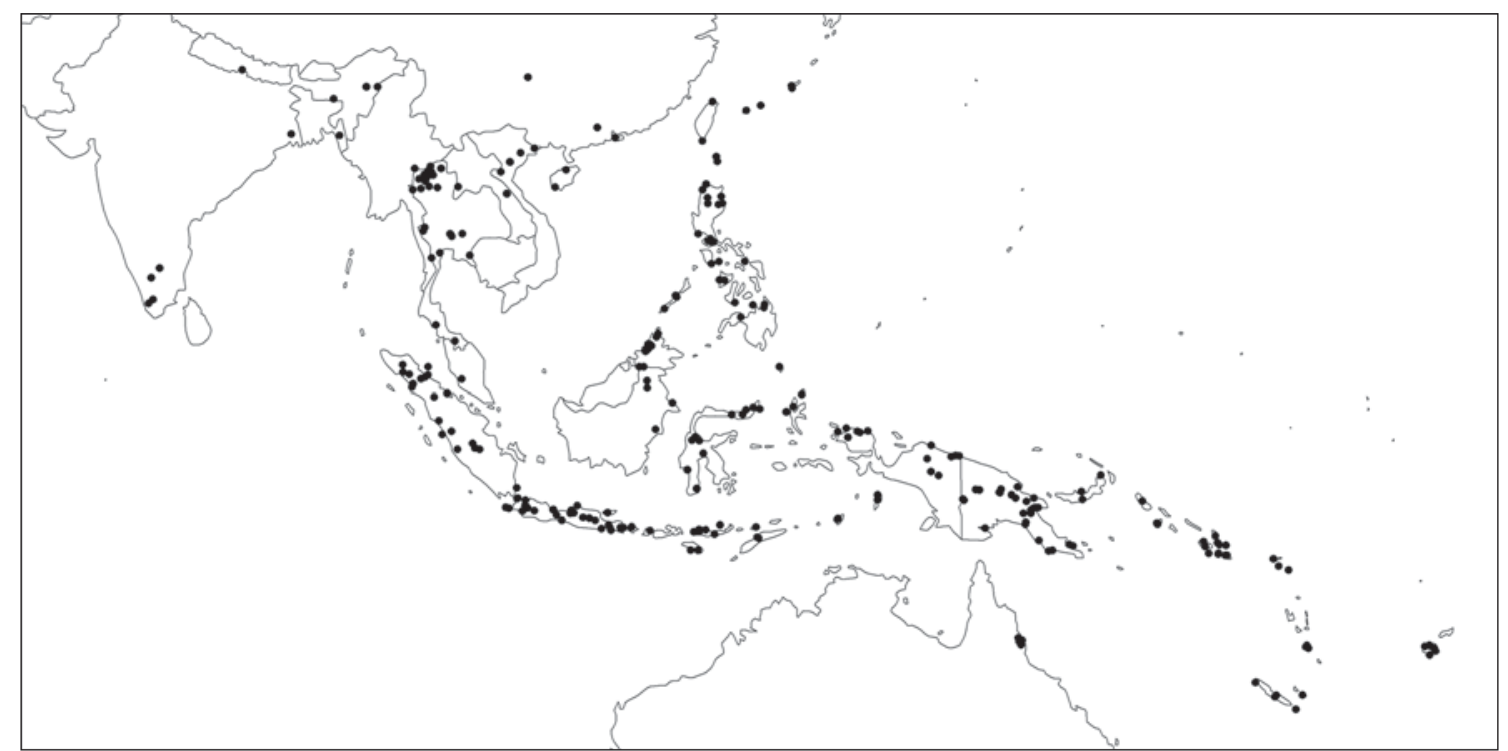

Map 1 Distribution of Bischofia javanica Blume. 


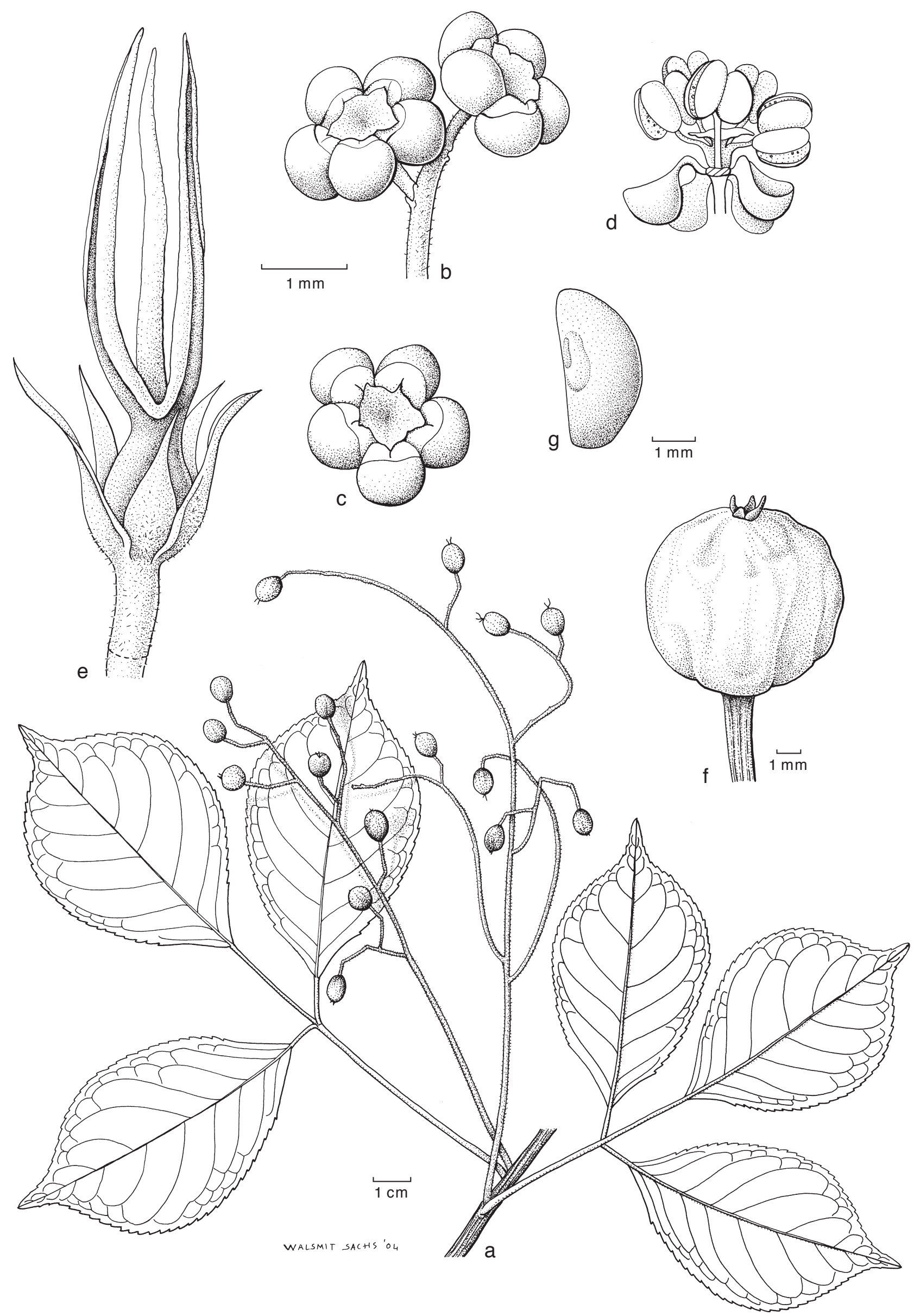

Fig. 1 Bischofia javanica Blume. a. Habit; b. young staminate flowers; c. staminate flower in apical view, sepals hooded over stamens, also pistillode visible; d. mature staminate flower with recurved sepals; e. pistillate flower; f. fruit; g. seed (a: Kostermans Khwae Noi Exp. 757; b-d: J.F. Maxwell 75-17; e: J.F. Maxwell 75-130; f, g: J.F. Maxwell 89-1514; all L). — Drawing by Anita Walsmit Sachs, 2004. Reproduced from Flora of Thailand 8, 2 with permission. 
Tree up to $40 \mathrm{~m}$ high, dbh up to $2 \mathrm{~m}$; buttresses often present, up to $0.5 \mathrm{~m}$ high, $1.5 \mathrm{~cm}$ out. Outer bark thin, up to $3 \mathrm{~mm}$ thick, slightly cracked to usually flaking with fibrous, thin strips (like Eucalyptus) or scaling, pale reddish to usually dark brown to grey-brown; inner bark up to $1 \mathrm{~cm}$ thick, red-brown to pink to light reddish to cream inside, soft; exudate red; sapwood white to light red, soft to hard; heartwood dark beefy red. Stipules c. 5 by $1.7 \mathrm{~mm}$. Leaves 3-foliolate; petiole $5.5-17.5 \mathrm{~cm}$ long, petiolules up to $6.5 \mathrm{~cm}$ long, especially central one longer; leaflets mainly elliptic, $5-18$ by $2.5-10 \mathrm{~cm}$, length/width ratio $1.4-2.3$, coriaceous when mature; base cuneate, occasionally with two glandular teeth at point of petiole insertion on upper surface, apex acuminate (to cuspidate), upper surface dark green, lower surface light green; nerves in 7-8 pairs. Inflorescences up to $32 \mathrm{~cm}$ long in fruit, branching often tomentose, glabrescent; bracts ovate, those to branches c. 4.3 by $1.8 \mathrm{~mm}$, those to flowers $0.8-2.6$ by $0.3-1.3 \mathrm{~mm}$. Staminate flowers c. $2.5 \mathrm{~mm}$ diam; red in bud, yellowish when open; pedicel c. $2.6 \mathrm{~mm}$ long; sepals ovate to almost circular, $1.2-2$ by $0.6-$ $1.1 \mathrm{~mm}$, light green, apex rounded, slightly hairy; torus c. 0.5 $\mathrm{mm}$ high; filaments $0.5-0.6 \mathrm{~mm}$ long, light green, anthers c. 1 by $0.8 \mathrm{~mm}$, yellow-green to light yellow. Pistillate flowers quickly developing into fruits; pedicel in fruit up to $11 \mathrm{~mm}$ long; sepals ovate, $2.1-4$ by $0.8-1 \mathrm{~mm}$, apex acute; staminodes up to c. 0.5 $\mathrm{mm}$ high; ovary green; style c. $0.7 \mathrm{~mm}$ long, stigmas $4.5-5$ $\mathrm{mm}$ long, whitish. Fruits dry $8-10$ by $7-10 \mathrm{~mm}$, wrinkled, dark red to brown. Seeds $4.2-4.8$ by $3.2-3.4$ by $2.5-3 \mathrm{~mm}$, brown.

Distribution - India (Assam, Kerala), Nepal, Bangladesh, China (Guangdong, Guizhou, Hainan, Hong Kong), Taiwan, Japan (Ryukyu Islands), Laos, Vietnam, Thailand, Malay Peninsula, Sumatra, Java, Borneo, the Philippines, Sulawesi, Lesser Sunda Islands, the Moluccas, New Guinea, the Solomon Islands, E Australia, New Caledonia, Vanuatu, Fiji, Tonga, Cook Islands. Note the absence in Cambodia.

Habitat \& Ecology - A pioneer species that occurs in many different, generally open habitats in primary wet evergreen to dry evergreen to deciduous to disturbed forest, beach forest, secondary montane forest, riparian forest, savannah, degraded scrub forest, thickets, village commons, fields; usually in wetter places, often along streams, mangrove edge, forest margins, roads; soils: on (peaty) sand, loam, clay, clay-loam, limestone, rock, coral reef, ultramafic. Altitude: sea level up to $1500(-2350) \mathrm{m}$. Flowering: March till May, November; fruiting: throughout the year. Fruits eaten by Oriolus birds, an invasive species in the Bonin Islands.

Vernacular names - Sumatra: Bintoeng, Bintoengan, Geroendjing, Gradjing, Kajoe sikkam, Kalek oeba, Kroendjing, Madangbienoengan; Kerindjing (Malay); Sikam (Timor); Singkam (Toba); Tingkem, Tjikam, Tjingham, Tjingkam, Tjinkam (Karo). Java: Gadok (Sundanese); Gendungan, Genlungan, Gi(e) ntoeng, Gintoengan. Borneo: Kalimantan: Bato (Dayak); Betoh; Sabah: Bongkoi; Kapas-kapas (Dusun-Kinabatangan); Tungou (Dusun); Sarawak: Buah jelintik, Merbak (Iban); Bual tu-arur (Kelabit). Philippines: Alimunos (East Cagayan); Guilon; Tuwod, Tuwol an aguyae (Ifugao). Sulawesi: Boeroenga, Kayawoe; Marintek (Tontembuan); Mau hal (Bunaq); Peti mati. Lesser Sunda Islands: Alor: Atait; Bali: Gintoengan; Flores: H. uwu, $\mathrm{Na}$; Sumba: Memala (Wuijewa); Ternate: Simamo; Timor: Wattoeng. New Guinea: Papua (Indonesia): Dafoa (Itik \& Mander); Defer (Berik); Goe (Karoon); Guddie (Kemtoek); Poem (Dani); Oewem, Wala (Mooi); Rikreu (Nemo); Senteroraar, Sentoroar, Sentroari, Toroep (Kebar); Sebie, Serbie, Siesemo (Manikiong); Papua New Guinea: Gugul (Utu); Gwek (Bembi); Keme (Kuman); Kena (Kopiago); Marramar (Miniafia, Utukap dial.); Morwar (Kaigorin); Nangum (Madang); Ruru (Wanigela); Simi (Rawa); Unai (Jal); Ur (Onjob, Koreaf dial.).

Uses - Medicinal use in China (Hainan); fruits eaten in Borneo (Sarawak); wood used for firewood in New Guinea and for fencing (poles easily sprout!) in the Solomon Islands; in the latter and in Tonga the squeezed bark or the latex is used with charcoal as a brown or black dye and for tanning strings and fishing nets in New Guinea. In Tonga the stem is used for handicrafts.

Note - Forman (1997) does not list Andrachne trifoliata (or any of the synonyms) in his list of possible Roxburgh type specimens or drawings. Specimens in Kew showing the name A. trifoliata have no original Roxburgh handwriting and one of them can at best be a neotype. Sanjappa et al. (1994) provide a list of Roxburgh drawings present in CAL. In their table 1 (titled 'plates absent in Kew') no. 1698 is a plate of $A$. trifoliata. Forman (1997) states that most of the plates absent in Kew do not depict Roxburgh species, except those listed by him; unfortunately he missed $A$. trifoliata.

\section{EXCLUDED SPECIES}

Bischofia cummingiana Decne. (1844) 153. - Type: Cuming 1174 (holo P, not seen; iso L, M), Philippines, Manila. = Litsea (Lauraceae). Identified as L. glutinosa (Lour.) C.B.Rob. var. littoralis Koord. \& Valeton in L, and as L. sebifera Pers. in M.

Note - Bischofia cummingiana is generally regarded as a synonym of B. javanica (e.g., Govaerts et al. 2000). Vidal y Soler (1885) interpreted Cumings collections, and he indicates that Cuming $1174=$ B. javanica, and Cuming $1185=$ Sterculia foetida $L$ (with an asterisk that it can be $B$. javanica based on Müller 1866). It may well be that other duplicates are indeed Bischofia, but when Decaisne's descriptions of the species are considered then a discrepancy appears, in most descriptions the leaflets ('foliolis') are mentioned, except for B. cummingiana, where Decaisne writes about leaves ('foliis'). Thus, obviously the type of $B$. cummingiana is likely not Bischofia with its 3(-5)-foliolate leaves. Cuming 1173 in $L$ has on the label 1174 ? next to 1173 , but this is a true $B$. javanica.

\section{HYMENOCARDIA}

Typical for Hymenocardia is the presence of disc-like glandular hairs, the strange staminate bracts, the lack of a disc, stamens with a gland on the connective, and the very flat, 2-locular, samara-like fruits.

The genus name (Greek: humên, humĕnos = fleece; kardĭa = heart) refers to the very flat, heart-shaped fruits (Backer 2000).

\section{Hymenocardia Wall. ex Lindl.}

Hymenocardia Wall. ex Lindl. (1836) 441; Endl. (1837) 288 (nr. 1899); Tul. (1851) 256; Baill. (1857) 994; (1858) 599, pl. 27: f. 24, 25; Müll.Arg. (1866) 476; Kurz (1877) 394; Benth. (1880) 285; Hook.f. (1887) 376; Pax (1890) 30; Pax \& K.Hoffm. (1922) 72; Gagnep. (1927) 543; Pax \& K.Hoffm. (1931) 51; Airy Shaw (1964) 262; (1972a) 363; Whitmore (1973) 103; Radcl.-Sm. (1987) 52; G.L.Webster (1994) 53; Govaerts et al. (2000) 1013; Radcl.Sm. (2001) 74; Welzen (2007) 341; G.L.Webster (2014) 82, f. 15. - Type: Hymenocardia punctata Wall. ex Lindl.

Samaropyxis Miq. (1860) 464. - Type: Samaropyxis elliptica Miq. (= Hymenocardia punctata Wall. ex Lindl.).

Shrubs to trees, dioecious, deciduous, leaves appearing during flowering; branches hairy with scale-like hairs and simple hairs when young. Indumentum of simple and scale-like hairs (recorded as glandular). Stipules triangular, thick, early caducous. Leaves distichous (to opposite) on branches, simple; petiole not pulvinate, reniform in transverse section; blades elliptic, margin entire, glabrous above to hairy on midrib with simple hairs, hairy beneath, venation densely reticulate, few nerves, latter looped and closed near margin. Inflorescences dense spikes 


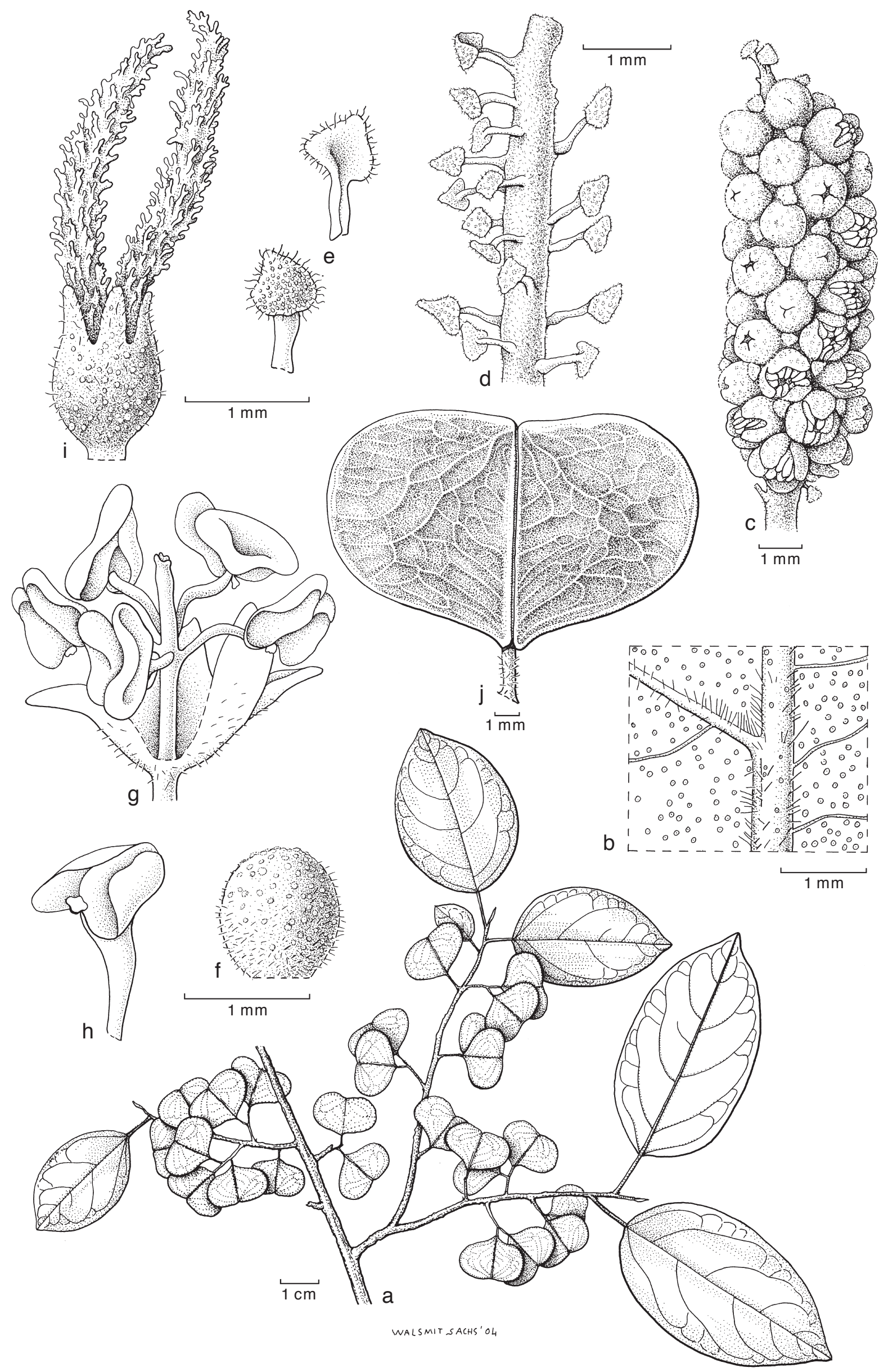

Fig. 2 Hymenocardia punctata Wall. ex Lindl. a. Habit; b. lower leaf surface with hair tuft domatium and glandular scales; c. staminate inflorescence; d. staminate inflorescence with only bracts; e. petioled bracts; f. staminate bud with scale hairs and normal hairs; g. staminate flower; h. stamen with dehisced thecae and gland on connective; i. pistillate flower; j. fruit (a, b, j: J.F. Maxwell 71-277; c-h: Koyama' Terao \& Wongprasert T-33007; i: J.F. Maxwell 72-64; all L). — Drawing by Anita Walsmit Sachs, 2004. Reproduced from Flora of Thailand 8, 2 with permission. 
to panicles, axillary and catkin-like when staminate, terminal and few-flowered racemes when pistillate; flowers bracteate. Flowers actinomorphic; petals and disc absent. Staminate flowers: pedicel very short; calyx mainly 5-lobed, cupular, lobes triangular, imbricate to almost valvate; stamens mainly 5 , episepalous, basally united or free, anthers very large, 2-thecate, dorsifixed, horizontal when dehiscing extrorse via lengthwise slits, connective with subapical, dorsal gland; pistillode on top of androphore, a short cylinder, apically slightly 2-lobed. Pistillate flowers shortly pedicelled, sepals (4-)5(-8), free, longtriangular, valvate, soon caducous leaving cup-shaped scars; ovary 2-locular, flattened; ovules 2 per locule; style absent or minute, stigmas 2, unlobed, long papillate. Fruits flat, 2-lobed, usually heart-shaped, samara-like capsules (rhegmas), winged or not. Seeds usually 1 per locule developed, naked.

Distribution - A genus of six species (Govaerts et al. 2000), of which five in continental Africa and one in Southeast Asia main land and $\mathrm{W}$ Malesia.

\section{Hymenocardia punctata Wall. ex Lindl. - Fig. 2; Map 2}

Hymenocardia punctata Wall. [(1831) nr. 3549] ex Lindl. (1836) 441; Hook.f. (1877) 377; Pax \& K.Hoffm. (1922) 72; Gagnep. (1927) 542; Airy Shaw (1972a) 363; Whitmore (1973) 103; Govaerts et al. (2000) 1013; Welzen (2007) 341, f. 10; pl. XIX: 1. - Lectotype (designated here): Wallich no. 3549 (K, K001119695; iso G, G-DC 2 sheets, K, K001119696), Burma, Moolmyne, river Akan? at Salum.

Hymenocardia wallichii Tul. (1851) 256; Müll.Arg. (1866) 476; Kurz (1877) 394; Pax \& K.Hoffm. (1922) 78, f. 8e; Gagnep. (1927) 544. - Type: Wallich no. 3549 (G-DC; iso G 2 sheets, $\mathrm{K} 2$ sheets), Burma, Moolmyne, river Akan? at Salum. N.B. same duplicates as for $H$. punctata.

Hymenocardia wallichii Tul. var. dasycarpa Gagnep. (1927) 546. - Type: Thorel s.n. (not seen), Cambodia, Compong-luong.

Samaropyxis elliptica Miq. (1860) 465. - Type: Teijsmann HB 4248 (holo U), Sumatra, prov. Lampong, prope Marassa.

Hymenocardia laotica Gagnep. (1923) 436; (1927) 546, f. 68: 1. - Type: Thorel 1283 (holo P; iso A), Laos, Stung-streng (A sheet: Me-Kong, Stong Treng).

Shrubs to trees up to $7 \mathrm{~m}$ high, dbh up to $9 \mathrm{~cm}$; flowering branches $2-4.5 \mathrm{~mm}$ thick. Bark thin, smooth to finely roughened to roughly cracked and flaking, grey to grey-brown. Indumentum

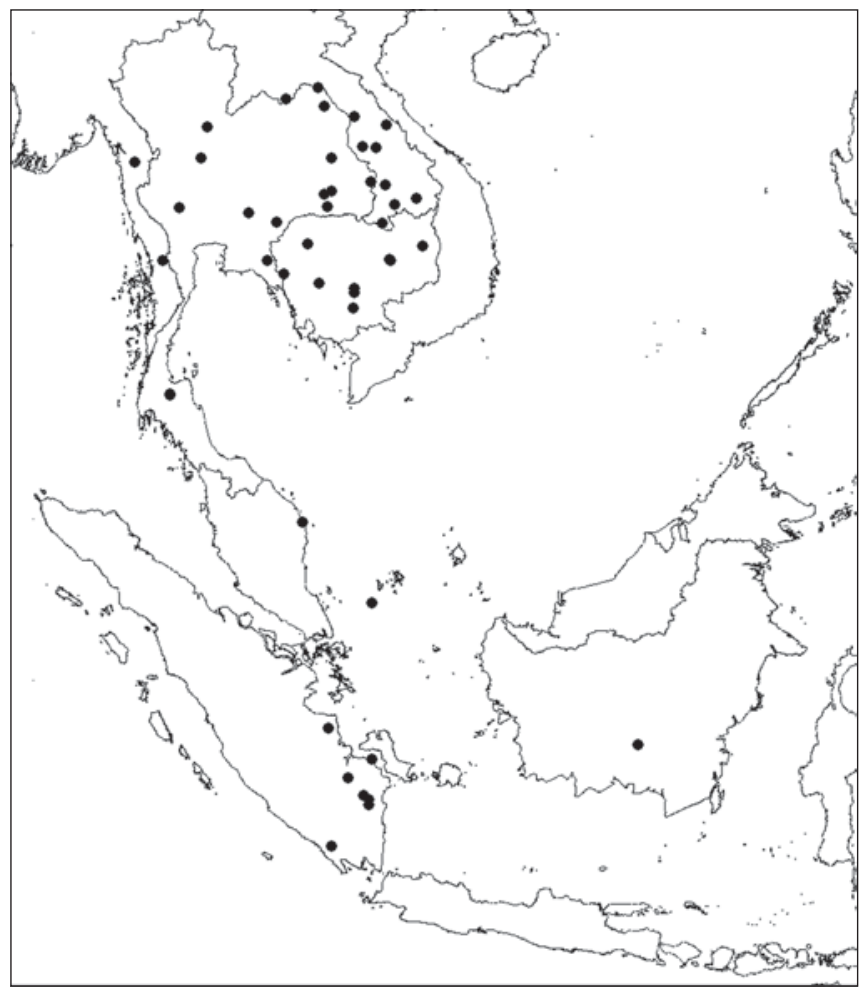

Map 2 Distribution of Hymenocardia punctata Wall. ex Lindl. present on most parts, scale-like hairs yellow, stipules and floral parts inside glabrous. Stipules $1-3$ by $0.2-1 \mathrm{~mm}$. Leaves: petiole $0.5-1.2 \mathrm{~cm}$, hairy, especially above; blade elliptic, $2.2-9$ by $1.4-5.2 \mathrm{~cm}$, length/width ratio 1.7-2.1, base emarginate to rounded (to cuneate), apex acute to acuminate, upper surface shiny, green, lower surface densely scaly, at most hairy on nerves and midrib, with (indistinct) hair tuft domatia, dull light green; venation sunken to slightly raised above, raised underneath, nerves 6-8 per side. Staminate inflorescences axillary catkins, up to $2.5 \mathrm{~cm}$ long, axes dull light yellow-green; bracts pedicelled, pedicel up to $0.5 \mathrm{~mm}$ long, blade subpeltate, triangular, c. 0.5 by $0.4 \mathrm{~mm}$. Staminate flowers c. $1.5 \mathrm{~mm}$ diam, red to purple; pedicel up to $0.5 \mathrm{~mm}$ long, calyx c. $1.5 \mathrm{~mm}$ long, lobes $0.4-0.7$ by $0.4-0.7 \mathrm{~mm}$, pale light greenish; stamens $4-5$, united with pistillode, androphore $0.4-0.5 \mathrm{~mm}$ long, filaments pale pinkish white, c. $1 \mathrm{~mm}$ long, anthers c. 1 by $0.7 \mathrm{~mm}$, dark red; pistillode c. $1.2 \mathrm{~mm}$ long. Pistillate inflorescences racemes, up to $2 \mathrm{~cm}$ long, axes grey-tan; bracts ovate, c. 1 by $1 \mathrm{~mm}$, dull light greenish, early caducous. Pistillate flowers c. $1 \mathrm{~mm}$ diam, brown; pedicel up to $2 \mathrm{~mm}$ long; sepals 5 , triangular, 0.7-1.2 by $0.3-0.5 \mathrm{~mm}$; ovary flat, \pm diamond-shaped, $0.3-1$ by $0.3-$ $1 \mathrm{~mm}$, green to glossy dark maroon; stigmas $1-15 \mathrm{~mm}$ long (elongating with age), maroon. Fruits not winged, heart-shaped with horizontal lobes, $1.6-2.1$ by $1.1-1.5 \mathrm{~cm}$, changing from maroon to brownish green to yellowish; columella very slender, c. $13.5 \mathrm{~mm}$ long, apically hardly broadened. Seed unripe?, flat, obovate, c. 6 by $3.5 \mathrm{~mm}$.

Distribution - Myanmar, Thailand, Laos, Cambodia, Malay Peninsula, Sumatra.

Habitat \& Ecology - In primary to secondary dry dipterocarp forest to mixed deciduous forest, very often along water, like along beaches, rivers, lakes, but also very often in open scrubs, roadsides or at the border between cultivated and natural vegetations. The plant is considered to be a pioneer. Soils generally wet; bedrock sand, sandstone, rhyolite. Altitude: sea level up to $235 \mathrm{~m}$. Flowering: October, December till May; fruiting: February till October.

Vernacular names - Sumatra: Mersepang, Sepang, Sesepang, Serpang.

Uses - Cambodia: Fruits sour, used in cooking. Bark and roots used medicinally.

\section{EXCLUDED SPECIES}

Hymenocardia plicata Kurz (1877) 395. — Lectotype (designated by Bollendorff et al. 2000: 331) Kurz 1554 (K), Burma, Tomkgeghat, 7 Pagodas $=$ Mallotus plicatus (Müll.Arg.) Airy Shaw (see Bollendorff et al. 2000).

Note - Probably described in Hymenocardia because of the heart-shaped, winged fruits and the presence of glandular, scale-like hairs. However, the indument (stellate hairs), and flowers are completely different, the fruits are 3-locular, instead of 2-locular, and the locules are thicker, not flat.

Acknowledgements The directors and keepers of G, K, L, P are thanked for photos or use of their collections. Jan Frits Veldkamp is thanked for translating some Latin text and advice on nomenclature. Anita Walsmit Sachs made the two beautiful drawings.

\section{REFERENCES}

Airy Shaw HK. 1964 '1965'. Diagnoses of new families, new names, etc., for the seventh edition of Willis's 'Dictionary'. Kew Bulletin 18: 249-273. Airy Shaw HK. 1972a. The Euphorbiaceae of Siam. Kew Bulletin 26: 191363.

Airy Shaw HK. 1972b. Nomenclatural note on Bischofia racemosa Cheng \& Chu (Bischofiaceae). Kew Bulletin 27: 271-272. 
Backer CA. 2000. Verklarend woordenboek van wetenschappelijke plantennamen (new ed.). Veen, Amsterdam, Antwerpen.

Backer CA, Bakhuizen van den Brink Jr RC. 1963. Flora of Java 1. Noordhoff, Groningen.

Baillon MH. 1857. Les Scépacées doivent-elles constituer un ordre particulier? Bulletin de la Société Botanique de France 4: 993-994.

Baillon MH. 1858. Étude Générale du groupe des Euphorbiacées. Librairie de Victor Masson, Paris.

Baillon MH. 1862. Species Euphorbiacearum. Euphorbiaceae Neo-Caledonicae. Adansonia 2: 211-248.

Beddome RH. 1872. The Flora Sylvatica for Southern India 2. Ganz Brothers, Madras.

Benneth JJ. 1840. Plantae Javanicae Rariores. Gul. H. Allen \& Socios, Londini.

Bentham G. 1880. Ordo CLI. Euphorbiaceae. In: Bentham G, Hooker JD (eds), Genera Plantarum 3, 1. Reeve \& Co, Londini.

Blume CL. 1826-1827. Bijdragen tot de Flora van Nederlandsch Indië 17. Lands Drukkerij, Batavia.

Bollendorff SM, Van Welzen PC, Slik JWF. 2000. A taxonomic revision of Mallotus section Polyadenii (Euphorbiaceae). Blumea 45: 319-340.

Brandis B. 1874. The Forest Flora of North-West and Central India. Allen \& Co., London.

Decaisne J. 1842. Bischoffia. In: d'Orbigny A(CVM)D (ed), Dictionnaire Universel d'Histoire Naturelle. Houssiaux \& Cie., Paris.

Decaisne J. 1844. Plantae Rariores quas in India Orientali collegit Victor Jacquemont. In: Jacquemont $\vee$ (ed), Voyage dans l'Inde 4: 57-180. Firmin Didot Frères, Paris.

Duan YF, Li YF, Yang XX, et al. 2016. Validation of the Chinese names Bischofia racemosa (Euphorbiaceae), Ulmus erythrocarpa and Ulmus multinervis (Ulmaceae). Phytotaxa 247: 151-152. http://dx.doi.org/10.11646/ phytotaxa.247.2.9.

Endlicher SL. 1837. Genera Plantarum 3. Fr Beck, Vindobonae.

Endlicher SL. 1840. Genera Plantarum 15. Fr Beck, Vindobonae.

Forman LL. 1997. Notes concerning the typification of names of William Roxburgh's species of Phanerogams. Kew Bulletin 52: 513-534.

Gagnepain F. 1923. Euphorbiacées nouvelles (Baccaurea, Bridelia, Godefroya, Hymenocardia). Bulletin de la Société Botanique de France 23: 431-437.

Gagnepain F. 1927. Euphorbiaceae. In: Lecomte MH (ed), Flore Générale de l'Indo-Chine 5. Masson \& Cie, Paris.

Gamble JS. 1881. A manual of Indian timbers. Sampson Low, Marston \& Company, London.

Govaerts R, Frodin DG, Radcliffe-Smith A. 2000. World checklist and bibliography of Euphorbiaceae (and Pandaceae) 1 \& 3. Royal Botanic Gardens, Kew.

Hasskarl JK. 1844. Catalogus Plantarum in Horto Botanico Bogoriensi Cultarum alter. Typis officinae publicae (Lands-Drukkerij), Bataviae.

Hata K, Suzuki JI, Kachi N, et al. 2006. A 19-year study on the dynamics of an invasive alien tree, Bischofia javanica, on a subtropical oceanic island. Pacific Science 60: 455-470.

Hoffmann P, Kathriarachchi H, Wurdack KJ. 2006. A phylogenetic classification of Phyllanthaceae (Malpighiales; Euphorbiaceae sensu lato). Kew Bulletin 61: 37-53.

Hooker JD. 1887. The Flora of British India 5. Reeve \& Co., London.

Hooker WJ. 1852. Bischofia trifoliata. Icones Plantarum 9: t. 844.

Hurusawa I. 1954. Eine nochmalige Durchsicht des herkömmlichen Systems der Euphorbiaceen im weiteren Sinne. Journal of the Faculty of Science, University of Tokyo, Section III, botany 6: 210-341.

Hutchinson J. 1969. Tribalism in the family Euphorbiaceae. American Journal of Botany 56: 738-758.

Kathriarachchi H, Hoffmann P, Samuel R, et al. 2005. Molecular phylogenetics of Phyllanthaceae inferred from five genes (plastid atpB, matK, 3'ndhF, rbcL, and nuclear PHYC). Molecular Phylogenetics and Evolution 36: 112-134.
Kurz S. 1877. Forest Flora of British Burma 2. Office of the Superintendent of Government Printing, Calcutta.

Levin GA. 1986. Systematic foliar morphology of Phyllanthoideae (Euphorbiaceae). III. Cladistic analysis. Systematic Botany 11: 515-330.

Li BT, Gilbert MG. 2008. Bischofia. In: Wu ZY, Raven PH (eds), Flora of China 11: 217, 218. Science Press, Beijing; Missouri Botanical Garden Press, St. Louis.

Lindley J. 1836. An introduction to the natural system of botany, ed. 2. Longman, Rees, Orme, Brown, Green, and Longman, London.

Miquel FAW. 1859. Flora van Nederlandsch Indië 1, 2. Van der Post, Amsterdam.

Miquel FAW. 1860. Flora van Nederlandsch Indië, Eerste bijvoegsel. Van der Post, Amsterdam.

Müller (Argoviensis) J. 1865. Euphorbiaceae. Linnaea 34: 1-224.

Müller (Argoviensis) J. 1866. Euphorbiaceae. In: De Candolle AP (ed), Prodromus Systematis Naturalis Regni Vegetabilis 15, 2. Victoris Masson \& Filii, Paris.

Pax F. 1890. Euphorbiaceae. In: Engler A, Prantl K (eds), Die natürlichen Pflanzenfamilien 3, 5: 1-119. Engelmann, Leipzig.

Pax F, Hoffmann K. 1922. Euphorbiaceae-Phyllanthoideae-Phyllantheae. In: Engler A (ed), Das Pflanzenreich IV.147.xv. Engelmann, Leipzig.

Pax F, Hoffmann K. 1931. Euphorbiaceae. In: Engler A, Harms H (eds), Die natürlichen Pflanzenfamilien, 2nd ed, 19c: 11-233. Engelmann, Leipzig.

Radcliffe-Smith A. 1987. Segregate families from the Euphorbiaceae. Botanical Journal of the Linnean Society 94: 47-66.

Radcliffe-Smith A. 2001. Genera Euphorbiacearum. Royal Botanic Gardens, Kew.

Roxburgh W. 1832. Flora Indica, ed. 1832, 3. Thacker \& Co., Calcutta; Parburry, Allen \& Co., London.

Sanjappa M, Thothathri K, Das AR. 1994 '1991'. Roxburgh's Flora Indica drawings at Calcutta. Bulletin of the Botanical Survey of India 33: 1-232.

Smith AC. 1981. Flora Vitiensis Nova 2. Pacific Tropical Botanical Garden, Lawai, Kauai, Hawaii.

Smith JJ. 1910. Euphorbiaceae. In: Koorders SH, Valeton T (eds), Bijdrage tot de kennis der boomsoorten op Java 12. Mededeelingen uitgaande van het Departement van Landbouw in Nederlandsch-Indië 10: 9-637.

Tulasne LR. 1851. Antidesmata et Stilaginellas, novum plantarum genus, recenset nonnullaque de eis affinibus. Annales Sciences Naturelles, Botanique sér. 3, 15: 180-266.

Van Welzen PC. 2005. Bischofia. In: Chayamarit K, Van Welzen PC (eds), Euphorbiaceae (Genera A-F). In: Santisuk T, Larsen K (eds), Flora of Thailand 8, 1: 122-126. The Forest Herbarium, Bangkok.

Van Welzen PC. 2007. Hymenocardia, Bischofia. In: Chayamarit K, Van Welzen PC (eds), Euphorbiaceae (Genera G-Z). In: Santisuk T, Larsen K (eds), Flora of Thailand 8, 2: 341-343, 610, respectively. The Forest Herbarium, Bangkok.

Vidal y Soler S. 1885. Phanerogamae Cumingianae Philippinarum. Pérez Hijo, Manila.

Wallich N. 1831, 1847. Numerical List. Hand written, London.

Webster GL. 1994. Synopsis of the genera and suprageneric taxa of Euphorbiaceae. Annals of the Missouri Botanical Garden 81: 33-144.

Webster GL. 2014. Euphorbiaceae. In: Kubitzki K (ed), The families and genera of vascular plants 11, Malpighiales: 51-216. Springer Verlag, Berlin, Heidelberg.

Whitmore TC. 1973. Tree Flora of Malaya 2. Longman, London.

Wight R. 1852. Icones Plantarum Indiae Orientalis 5. Franck \& Co., Madras. Wight R, Arnott GAW. 1833. Characters of some new or little known genera of plants. The Edinburgh New Philosophical Journal 14: 297-300.

Yazaki K, Kuroda K, Nakano T, et al. 2015. Recovery of physiological traits in saplings of invasive Bischofia tree compared with three species native to the Bonin Islands under successive drought and irrigation cycles. PlosOne 10: e0135117 (doi: 10.1371/journal.pone.0135117).

\section{IDENTIFICATION LIST}

\section{1 = Bischofia javanica Blume}

Alston 15826: 1 - Arances, Amoroso \& Ridsdale T/65: 1 - Atmodjo 434: 1 ; 453: 1 - Avé 4683: 1

Backer 8082: 1 - Bakhuizen van den Brink Jr 3376: 1 - Balansa (New Caledonia) 1818: 1 - Baumann-Bodenheim 14761: 1 - bb series 1794: 1; 4163 : 1; 4921: 1; 5352: 1; 5925: 1; 6082: 1; 8230: 1; 8420: 1; 8479: 1; 8931: 1; 9254: 1 ; 9301: 1 ; 15978: 1 ; 18775: 1; 19451: 1; 22479: 1; 23325: 1; 23774: 1; 23895: 1; 24396: 1; 24427: 1; 25005: 1; 25266: 1; 25422: 1; 28961: 1; 32489: 1 - Beccari PS 655: 1 - Becking 66: 1; 141: 1 - Béguin 696: 1 Bennett RSNH 4003: 1 - Blume 154: 1 - Bouamanivong 1: 2 - Brass 7391: 1; 21768: 1; 32510: 1 - Brass \& Versteegh 11165: 1 - BS series 1357:

\section{2 = Hymenocardia punctata Wall. ex Lindl.}

1 - BSIP series 43: 1; 1721: 1; 4499: 1; 6311: 1; 9879: 1; 9914: 1; 10154 ; 1; 10342: 1; 10440: 1; 10807: 1; 11292: 1; 11757: 1; 12687: 1; 14339: 1 ; 15573: 1; 15667: 1; 15735: 1; 16632: 1; 19493: 1 - BW series 706: 1; 2757 : 1; 3981: 1 ; 4640: 1 ; 5341: 1 ; 5680: 1 ; 7210: 1 ; 7853: 1; 7895: 1; 9364: 1; 9366: 1; 10943: 1; 11012: 1; 11644: 1; 12495: 1; 12522: 1; 12781: 1. Carr 14128: 1 ; 15774: 1 - Chew et al. RSNB 2624: 1 - Chun \& Tso 44266: 1 - Clemens 10875T: 1 - Clemens \& Clemens 30305: 1 - Coode \& Fernando 5265: 1 - Corner RSS 60: 1 - Craven \& Schodde 935: 1 - Cuming 1173: 1 . d'Alleizette 6437: 2 - Däniker 1340: 1 - De Vogel 5643: 1 - De Vogel \& Vermeulen 6633: 1 - De Voogd 91: 2 - De Wilde \& De Wilde-Duyfjes 
12783: 1 ; 14866: 1 ; 14867: 1 ; 16977: 1 ; 18082: 1 ; 18933: 1; 20325: 1 - De Wit 7: 1 - Degener 14297: 1; 14935: 1 - Dickason 6879: 2 - Diepenhorst 2137: 1 - Dockrill 94: 1

Elbert 4107: 1; 4107a: 1 - Elliott s004b4: 1 - Elmer 8474: 1; 8968: 1; 10125: 1; 13895: 1; 17619: 1 - Endert 267: 2; 268: 2; 269: 2; E822: 2; 1510: 1; 3507: 1.

Falconer 942: 1 - FB series 3497: 1; 10680: 1; 10752: 1; 10986: 1; 12774 : 1 - Florence 10383: 1 - Fosberg 38061: 1; 38370: 1 - Friedberg 266a: 1. Galih 1: 2 - Gallatly 457: 2; 567: 2 - Gardner \& Sidisunthorn 2126: 1 Geesink, Phanichapol \& Santisuk 5899: 1 - Gillison RSNH 3504: 1 - Gray 1016: 1; 1388: 1; 2195: 1; 2787: 1; 3580: 1; 4863: 1 - Green RSNH 1078: 1 - Greenwood 345B: 1 - Greijmans 79: 2.

Hartley 10945: 1; 10990: 1; 12268: 1 - Hatusima 17262: 1 - Hidayat 137: 1 - Hohenacker 1559: 1; 1573: 1 - Hoogland 4719: 1; 4939: 1 - Hotta 4528: 1 - Houtsoorten van den Gedeh (Java) 63: 1; 168: 1 - How 70481: 1 - Hu \& But 20979: 1 - Huq et al. 10471: 1; 10822: 2 - Hyland 1523: 1; 7242: 1 ; 25229RFK: 1.

Ja series 2003: 1 - Jaag 370: 1.

Kairo 476: 1 - Kajewski 1877: 1 - Kalshoven 11: 1 - Keng 1064: 1-KEP FRI series 29018: 1 - Kerr 2504: 1; 5119: 1; 9963: 1; 12438: 1; 17880: 2 - King 5426: 2 - Koelz 25528a: 1; 25583a: 1; 29848: 1; 29889: 1 - Koop 159: 1 - Koorders 1918: 1; 1919: 1; 1921: 1; 1922: 1; 1923: 1; 1924: 1; 1925: 1; 1927: 1; 1928: 1; 1929: 1; 1930: 1; 1931: 1; 1933: 1; 1934: 1; 1935: 1; 1937: 1 ; 1938: 1 ; 1939: 1 ; 1940: 1 ; 1941: 1 ; 1943: 1; 1945: 1; 1946: 1; 1947 : 1; 1949: 1 ; 1950: 1; 1951: 1 ; 1952: 1; 1953: 1; 1956: 1; 10952: 1; 11254: 1; 11441: 1 ; 11442: 1; 12249: 1; 12278: 1 ; 12308: 1; 13305: 1; 13327: 1 ; 13962: 1; 13990: 1; 16817: 1 ; 16818: 1 ; 20128: 1 ; 21052: 1 ; 22117: 1 ; 22574: 1 ; 22749: 1 ; 24202: 1 ; 24704: 1 ; 26174: 1; 27152: 1 ; 27737: 1 ; 28726: 1 ; 28938: 1; 29920: 1; 30144: 1 ; 33199: 1 ; 37036: 1 ; 37037: 1 ; 37057: 1 ; 38362: 1; 38458: 1; 38687: 1 ; 38802: 1 ; 38883: 1 ; 38904: 1 ; 39346: 1 - Kooy 488: 1 - Kostermans (Khwae) 757: 1; 1353: 1; 5969: 1; 6230a: 1; 7009: 1; 10482: 2 - Kostermans \& Wirawan 468: 1 - Koyama, Terao \& Wongprasert T-33007: 2 - Krukoff 4380: 1.

LAE series 56766: 1 - Lam 2901: 1 - Larsen 8389: 2 - Lau 2038: 1 - Lécard 122B: 1 - Lei 208: 1 - Liao 10543: 1 - Libman, Souliya \& Vanavong LAOS 552: 2 - Lörzing 5586: 1; 12837: 1; 15047: 1.

MacKee 22574: 1; 22580: 1; 23569: 1; 34129: 1 - Mangen 367: 1 - Martin 21: 2; 154: 2 - Maxwell 01-116: 1; 01-185: 2; 01-237: 2; 07-125: 2; 07-151: 2; 07-715: 2; 71-277: 2; 72-64: 2; 74-683: 1; 75-17: 1; 75-130: 1; 75-525: 1; 76-490: 2; 87-1311: 1; 88-261: 1; 88-1252: 1; 89-1276: 1; 89-1514: 1;
90-1140: 1; 94-756: 1; 95-253: 1; 95-435: 1; 95-593: 1; 97-634: 1; 98-435 2; 98-463: 2; 99-293: 1 - McDonald \& Afriastini 3303: 1 - McDonald \& Ismail 4967: 1 - Meijer 10533: 1 - Metzner 167: 1 - Middleton \& Lamxay 274: 2 - Middleton et al. 3336: 1 - Mikage et al. 9612090: 1 - Mogea 2497: 1 - Moran 5049: 1 - Moriarty 1932: 1 - Mousset 910: 1 - Murata et al. T-37776: 2; T-37789: 2; T-37810: 2; T-37827: 2.

Newman et al. LAO 783: 1 - NGF series 1163: 1; 1248: 1; 1399: 1; 3338: 1; 4007: 1 ; 6500: 1 ; 14826: 1; 16742: 1; 17016: 1 ; 18344: 1; 19439: 1; 20596: 1; 21646: 1 ; 21906: 1 ; 35224: 1 ; 35385: 1; 38619: 1; 41022: 1 ; 41615: 1 - Noerkas 378: 1 - Nooteboom 1345: 1.

Parakosonh, Kien \& Sinh 166: 2 - Parham et al. 15375: 1 - Pereira et al. 151: 1; 152: 1 - Philipson 10104: 1 - Phusomsaeng 47a (1967): 2; 358 (1970): 1 - PNH series 78273: 1; 78712: 1; 80471: 1; 150031: 1 - Poilane 22858bis: 2 - Pooma et al. 2149: 2; 5169: 2; 6277: 2 - Posthumus 1044: 1 - PPI series 1575: 1; 3070: 1; 7139: 1; 10401: 1; 10467: 1; 17229: 1 ; 17232: 1 ; 17931: 1; 17932: 1; 18366: 1; 18694: 1; 19914: 1; 21808: 1; 22725: 1; 23728 1; 23922: 1; 23952: 1; 24567: 1; 29625: 1.

Rahmat Si Boeea 3558: 1 - Ramadhanil et al. 398: 1; 446: 1 - Ramos 1022: 1 - Rau 244: 1 - RHT series 11094: 1 - Ridsdale 13: 1; 479: 1 - Rijksen 13974B: 1 ; 28973: 1.

S series 35541: 1; 71998: 1 - SAN series 16320: 1; 33146: 1; 44343: 1; 44575: 1; 51373: 1; 92523: 1; 116172: 1; 125913: 1; 128640: 1 - B. Sangkhachand 1372: 1 - Sanitjan 12: 1 - Schmutz 617a: 1 - Schodde \& Craven 4688: 1 - Schürmann 132: 1 - Sidiyasa et al. 2304: 2 - Sinclair 9993: 1 - A.C. Smith 4110: 1; 6045: 1; 7223: 1; 9405: 1 - Soejarto \& Southavong 10767: 2 - Soejarto et al. 5842: 1; 8300: 1; 9148: 1; 10190: 1; 10350b: 1 ; 10422: 1 - Soepadmo \& Mahmud HUM 9187: 2 - Sohma et al. 715306: 1 - Sterly 80-218: 1 - Svengsuksa et al. BT 2: 2 - Sykes Cl-1418: 1.

Takeuchi 4596: 1 - Teijsmann HB 4248: 2 - Teng 90856: 1 - Thorel 1283: 2 - Ting \& Chen 481: 1 - Tsang 29206: 1; 29933: 1; 30319: 1.

Unknown HB 638: 1 - UPNG series 7501: 1.

Van Beusekom \& Phengklai 2664: 1 - Van Beusekom et al. 3570: 1 - Van Daalen 434: 1 - Van Schaik \& van Noordwijk 191: 1 - Van Welzen 2003-7: 1 - Vannachak, Ridsdale \& Satdhychanh BT 1049: 2 - Vannachak et al. BT 825: 1 - Varadarajan et al. 1534: 1 - Verheijen 1241: 1; 1242: 1; 1243 : 1; 2950: 1; 2976: 1 - Vieillard 1162: 1.

Waterhouse 914: 1 - Whitmore \& Sidiyasa 3318: 1 - Wight (KD) 941: 1; KD 2600: 1 - Williams \& Pooma 1527: 2 - Winckel 318: 1 - Wirawan 355: 1. Yuncker 15042: 1; 15313: 1; 15856: 1; 16122: 1. 